\title{
COMPARISON ON NATIONAL SECURITY STRATEGY 2002 AND 2006: TO WHAT EXTENT DID NEOCONSERVATIVES INFLUENCE PERCEPTION OF THE US FOREIGN AND SECURITY POLICY OF THE SECOND PRESIDENTIAL ADMINISTRATION OF GEORGE W. BUSH?
}

The purpose of this article is to identify differences in the perception of the US foreign and security policy by the first and the second Bush presidency. Due to the fact that both presidencies of George W. Bush were strongly influenced by neoconservative view on the US role in the World, the first chapter is dedicated to the impact of neoconservativism on foreign and security policy of President George W. Bush. Finally, it introduces reader to basic principles of President's Bush foreign and security policy implemented after September 11 terrorist attacks.

The second chapter is the core chapter. It compares two major documents of Bush Administrations, which materialized his foreign and security policies. These are National Security Strategy 2002 and National Security Strategy 2006.

Key words: Neoconservativism, Democracy, Unilateralism, Pre-emptive strikes, "Bush Doctrine”, War on Terror, National Security Strategy

\section{Introduction}

It is generally agreed that Presidential Elections of 2000 were one of the most controversial elections in the history of the United States of America (the US). At that time, no one could anticipate that in foreseen future the same would be said about the presidential administration of George W. Bush. In respect to the US foreign and security policy, one could observe a rise of a unilateral approach, as well as ad-hoc solutions to global problems. Such approach brought the US into open misunderstandings with its closest allies and worsened the US relations with its global partners. This fact can be stated especially about the first presidency of George W. Bush, which was shadowed by the US intervention in Iraq and Afghanistan that worsened the US international reputation. The second presidency was marked by George W. Bush's efforts to improve international reputation of the US, as well as to repair its trans-Atlantic partnership with its closest allies in Europe. While we can argue about the extent of success of both presidencies, one fact cannot be denied. It is the fact that neoconservative thinking influenced both presidencies. The question that one might ask is whether there was a stronger neoconservative influence during the first or the second presidency, or if it remained the same throughout all eight years of George W. Bush presidency. The answer to this question could be found in the most essential documents that shaped the US foreign policy. These are the National Security
Strategy 2002 (NSS 2002) and its modification from 2006 (NSS 2006). The article will compare both national security strategies in order to answer this question.

\subsection{The purpose of national security strategy}

Under the current international system, it is responsibility of every state to guarantee its security, which is the precondition for development in the widest meaning of this term. In order to fulfil this task, each state must define a strategy necessary for its survival and development. The US Department of Defence defines strategy as "the art of science of developing and using political, economic, technological, psychological and military forces as necessary during peace and war to afford the maximum support to policies, in order to increase the probabilities and favourable consequences of victory and to lessen the chance of defeat" [1]. Since this represents more a military view on strategy, such definition could be misunderstood as primarily referring to military power. For purposes of this article we need a more comprehensive definition of strategy that could be called National Security Strategy. National Security Strategy could be seen as the application of the means to achieve a political objective; and consequently, as the art of using all elements of power of either a nation or an alliance of nations to accomplish a politically agreed aim, and the objectives of a nation of an alliance

\footnotetext{
* Pavel Necas ${ }^{1}$, Miroslav Kelemen ${ }^{1}$, Blazej Lippay ${ }^{2}$

${ }^{1}$ Armed Forces Academy of General Milan Rastislav Stefanik, Liptovsky Mikulas, Slovakia, E-mail: pavel.necas@aos.sk

${ }^{2}$ Dvojkrizna 2, 82107 Bratislava, Slovakia
} 
of nations in peace and war. Therefore, it must comprise the carefully coordinated and fully integrated use of all political, economic, military, cultural, social, moral, spiritual and psychological power available [2].

In order for any National Security Strategy to succeed, it must meet several core principles. First of all, such strategy must be protective and proactive strategy, not a reactive one. Thus any strategy must overcome the initial disadvantage of being forced to react by striving to quickly regain and maintain the initiative. The second core principle is proportionality, which aims to win hearts and minds of the people in the operation zone. This is a vital instrument in persuading one-time opponents to cooperate and even become partners after the conflict is over. The third, and not less important, core principle is damage limitation, which requires looking at actions taken during crisis or conflict through the lens of the postconflict period. The last core principle is a principle of legality. This means that all actions taken must be legitimate, properly authorized and in general accordance with customary international law [3]

\section{Neoconzervativism as a Backbone of Bush's Foreign and security policy}

Neoconservativism represents a philosophy of political right, which was developed in the US and which calls for the use of the US economic and military power to promote its economic, democratic, and human rights values globally [4]. This political philosophy became the central theme of the US foreign and security policies throughout both presidencies of George W. Bush from 2000 to 2008. Therefore, it is not a surprise that NSS 2002 and NSS 2006 were significantly influenced by such political perception, known as "Bush Doctrine".

The term "Bush Doctrine" was introduced for a first time in June 2001 in reaction to the US one-sided withdrawal from the Anti-Ballistic Missile Treaty (ABM) and Kyoto Protocol [5]. By the term "Bush Doctrine" it can be understood several mutually interconnected principles of foreign policy exercised under both presidencies of George W. Bush. Its roots can be tracked into the early nineties of the $20^{\text {th }}$ century. In 1992, former Secretary of Defence Richard Cheney openly stated for a first time that the US should never allow any other nation to become competitive superpower to the US. One of the founding fathers of this idea was also Paul Wolfowitz, who along with Donald Rumsfeld, Richard Cheney and other neoconservatives established a think-tank Project for New American Century (PNAC). One of the most famous PNAC initiatives was addressing an open letter to President Clinton, which called for removal of Saddam Hussein from power even by use of military force, if necessary. This idea was quickly adopted by George W. Bush administration even prior to September 11, 2001 [6].

In reaction to the terrorist attacks on World Trade Center and Pentagon on September 11, 2001, President Bush introduced a radical shift in the US foreign policy, which was based on four main pillars.
The first pillar was the US inclination to conduct pre-emptive strikes in order to safeguard its security. President Bush officially announced this decision during his speech at West Point Military Academy on June 1, 2002, when he stated:

"We cannot defend America and our friends by hoping for the best. We cannot put our faith in the word of tyrants, who solemnly sign non-proliferation treaties, and then systemically break them. If we wait for threats to fully materialize, we will have waited too long - Our security will require transforming the military you will lead - a military that must be ready to strike at a moment's notice in any dark corner of the world. And our security will require all Americans to be forward-looking and resolute, to be ready for preemptive action when necessary to defend our liberty and to defend our lives" [7].

The second pillar of this policy was the US readiness to promote democracy worldwide. Throughout the years from 2001 to 2004, President George W. Bush expressed his opinion several times that the US should, as part of its strategy on the War on Terror, actively support regime change around the globe. This was true especially for the region of Middle East. During his State of the Union address in 2003 President Bush declared:

"Americans are a free people, who know that freedom is the right of every person and the future of every nation. The liberty we prize is not America's gift to the world, it is God's gift to humanity." [8]

Similarly, during his speech at National Security University in 2005 President Bush stated that:

"The defense of freedom requires the advance of freedom." [9]

The third pillar of the "Bush Doctrine" was eagerness to intervene in countries that harbour terrorism. During his Address to the Nation on September 11, 2001, President Bush stated that the US would make no difference between those who commit acts of terrorism and those who harbour terrorists. This statement was later on reassured during his address to both Chambers of the US Congress on September 20, 2001, when he stated:

„We will pursue nations that provide aid or safe haven to terrorism. Every nation, in every region, now has a decision to make. Either you are with us, or you are with the terrorists. From this day forward, any nation that continues to harbor or support terrorism will be regarded by the United States as a hostile regime“ [10].

As it is well known, this policy became the reason for the US intervention in Afghanistan.

The fourth pillar of the "Bush Doctrine" was the US will to provide its security even when it would require taking unilateral actions regardless of approval from the international community. As it was already mentioned, this approach was visible immedi- 
ately at the beginning of Bush Presidency, when the US withdrew from the ABM Treaty.

The above mentioned four pillars of the "Bush Doctrine" were incorporated into both, National Security Strategy 2002 and National Security Strategy 2006, which became alpha and omega of the US foreign policy under President George W. Bush, and whose impact we observe even today.

\section{Comparison of NSS 2002 and NSS 2006}

Despite the fact that NSS 2002 and NSS 2006 were two different documents, they were strongly influenced by ideological background of Bush administration. Not surprisingly, these documents represent neoconservative perception of the US role in the field of foreign policy. The major difference between these two documents is the fact that when compared to NSS 2002, NSS 2006 takes into account the development in international relations throughout the period from 2002 to 2006. In other words, NSS 2006 is rephrased and adjusted NSS 2002. Before the comparison of NSS 2002 and 2006 is discussed, it would be useful to remind the reader briefly about the time when NSS 2006 was published.

Back in 2006, the US was engaged in the War on Terror for five years. Its major battlefields were located in Iraq and Afghanistan. The war however was developing in a different path than originally anticipated by President Bush. Taliban was defeated neither militarily nor politically. The opposite was true. Due to incompetence of democratically elected Afghan president to provide Afghan population with basic needs, Taliban was gaining in strength and in numbers. Moreover, the same as during the Soviet-Afghan War from 1979 to 1989 , enemy combatants successfully enlarged their area of operation also into northern Pakistan [11]. In Iraq, sectarian violence among Shia and Sunny Muslims, and Kurds broke up. Furthermore, in central Iraq a strong guerrilla movement, composed of former Iraqi Army soldiers, established itself with the aim to fight occupying troops. Terrorist group al-Qaeda was defeated neither. It continued to plan and to carry out its terrorists attacks, however one must admit that it was not in such scale as on September 11, 2001 for example. Palestinian-Israeli conflict reached a new peak as the result of Bush one-sided policy toward this region. Surprisingly, after the fall of Saddam Hussein, Iran became the only state in the region that benefited from worsen development in the Middle East. These are the facts one must take into account when comparing NSS 2002 with NSS 2006.

\subsection{Presidential remarks}

In his introduction to NSS 2002, President Bush highlights the importance of geopolitical and economic changes in the nations of former Eastern Bloc. At the same time, he reconfirms the US position as a solely superpower, which enjoys a position of unparalleled military strengths and great economic and political influence. According to him, the US is eager to take advantage of its unprecedented political, economic, and military potential and to spread values of democracy and free market economy globally. This approach became a central theme of NSS 2002. President Bush also admits that on the eve of the $21^{\text {st }}$ Century the US faces asymmetric security threats, whose prevention will require cooperation of entire US security establishment. The primary threat to the US security lies at the crossroads of radicalism and technology. In this respect, President Bush reconfirms his readiness to face such threat even by taking a unilateral approach. Moreover, he openly declares the US will to carry out pre-emptive strikes if necessary.

The introduction to NSS 2006 is untraditional one. President Bush declares that the US is in war, and NSS 2006 is a war strategy, whose purpose is to protect the US citizens against terrorism. In his opinion, this situation represents an opportunity for the US to lay down the foundation for future peace. The future peace can be achieved only under the condition that the War on Terror is won and democracy is spread globally. This is the key philosophy behind NSS 2006. In respect to the US foreign policy, President Bush evaluates his foreign policy for the period from 2002 to 2006. In comparison to NSS 2002, he recognizes the need to move from unilateral approach to the multilateral one. Such multilateral approach however should be taken under the leadership of the US only. He concludes his opening statement with reassurance that despite the fact the US is idealistic in its national interests, it is realistic in the means necessary for fulfilling them.

\subsection{Content of the US national security strategy}

NSS 2002 admits that the US possesses unprecedented strength and influence in the world, which obligates the US to spread political and economic freedom, peaceful relations with other states, and respect for human dignity. From the US point of view, it can be stated that after the century of struggle between freedom and totalitarianism, freedom has won. However, this does not necessarily means that the world is any safer. In the $21^{\text {st }}$ Century, the US is threatened not by conquering states but rather by failing ones. Therefore, the US must take advantage of its position and to spread the ideas of political and economic freedom, peaceful coexistence with other states, and respect of human rights. This should be achieved by championing for human dignity; strengthening alliances to defeat global terrorism; working with others to defuse regional conflicts; preventing the US enemies from threatening the US and its allies and friends with weapons of mass destruction (WMD); igniting a new era of global economic growth through promotion of free markets and free trade; expanding the circle of development by opening societies to democracy; developing agendas for cooperative action with other main centres of global power; and transforming America's national security institutions to meet the challenges and opportunities of the twenty-first century. NSS 2006 reaffirms the core ideas of NSS 2002.

The only difference in NSS 2006 is the fact that NSS 2006 emphasizes on phenomenon of globalization. In respect to globalization, the US is eager to engage with opportunities offered by this phenomenon on one hand, and confront its challenges on the other. 
When studying the above-mentioned content of both national security strategies, it can be argued that both strategies are comprehensively well-balanced documents, adequately responding to threats of global security environment in the $21^{\text {st }}$ Century. This is true despite the fact that the foundation of these strategies is clearly based on four neoconservative pillars described above.

NSS 2002 as well as NSS 2006 declares the US readiness to spread democracy, which is perceived as a tool to all global challenges, by all available means. This is a key philosophy, which was thoroughly exercised during both presidencies starting from 2000 to 2008 .

Secondly, NSS 2002 and NSS 2006 reaffirms the readiness to conduct pre-emptive strikes toward states trying to acquire weapons of mass destruction and means of their deployment, as well as states harbouring terrorists. Despite the fact that unilateral use of power was visible especially during the first presidency, by invading Iraq and Afghanistan, this principle was not totally abandoned during the period from 2004 - 2008. The difference however was the method applied to fulfil this principle. During the second presidency of George W. Bush, the US was applying multilateral approach. The prime example of this shift was the case of Iran, when the US worked closely with its allies and other regional partners to resolve this issue.

The Third neoconservative pillar, on which both documents were built on, is waging War on Terror. During both presidencies of George W. Bush, the US did not negotiate on this principle. Besides the direct military involvement in Iraq and Afghanistan, the US was working closely with its allies and partners to disturb terrorist networks around the globe. This included military, economic, law enforcement, and intelligence cooperation with all the nations facing this threat. Such cooperation took place throughout the whole period starting after September 11 terrorist attacks in 2001 and lasted until the end of the second presidency of George W. Bush in 2008.

The fourth, and the last, neoconservative pillar incorporated into NSS 2002 and NSS 2006 is prevention of the rise of a peer military competitor to the US. [12] With arrival of President Bush into the White House, we could witness a significant growth in military spending. Such increases in military spending were not related only to the US involvement in the War on Terror. The significant proportion of the defence budged was dedicated to projects aiming to qualitatively reshape the US military. This included launching wide number of new modernization projects for the US Armed Forces starting with stealth fighter projects and ending with the US anti ballistic missile systems. The objective of these efforts was clearly to guarantee the US military superiority over existing as well as potential canters of power.

\section{Conclusion}

The aim of this article was to compare perception of the US foreign and security policy by the first and the second presidential administration of George W. Bush and to identify to what extent they were influenced by neoconservativism. When elaborating on this topic, the authors focused their attention particularly on National Security Strategy from 2002 and its modification from 2006, which materialized President Bush's perception and ambitions in foreign and security field.

In general, it can be stated without any hesitations that both presidencies were significantly influenced by neoconservative perception of the US role in foreign and security affairs. When comparing the first presidency to the second one, one may observe that the second presidency already reflected on the development and the US experience in international arena throughout the period from 2002 to 2006

While both National Security Strategies come from the same ideological background one cannot deny differences between them. The fundamental difference between both presidencies of George $\mathrm{W}$. Bush is the fact that during his second term in the office he took into account the necessity of multilateral approach when dealing with global issues. Additionally, globalization was given an attention as a phenomenon, which must be taken into account when dealing with challenges to the US national security. Despite the fact that both Strategies met the criteria introduced at the beginning of this article, they failed to meet their goals. Forceful spreading of democracy proved to be a failure. With spreading of democracy in Afghanistan and Iraq, the US military presence in the region of Middle East and Central Asia heavily depended on cooperation with surrounding regional authoritarian regimes. These regimes were not very different from those of Saddam Hussein's. As a prime example of such regimes, we can mention Uzbekistan, Turkmenistan, Egypt and others. Moreover, even when a specific authoritarian regime was toppled down, the new one that came to power was not less corrupted or more eager to stand up for democratic values. The excellent example is Pakistan. In terms of the second and the third neoconservative pillar, conducting pre-emptive strikes and waging War on Terror, these proved to be another failure. Almost ten years after invading Afghanistan and Iraq, the world is safer neither from terrorism, nor from potential misuse of weapons of mass destructions. The contrary is true. By invading these countries, the US committed itself into long lasting high intensity conflicts, which require massive military presence that may needed elsewhere in defending the US interests. Moreover, these conflicts created justification for terrorists to carry out their sinister activities and thus created a large pool of potential US adversaries. The fourth pillar, to prevent others to become the US peer competitor, proved to be failure as well. This goal is unattainable from a longterm point of view. Simply by committing a huge amount of scarce resources to long-lasting overseas regional conflicts there was not enough resources for well-proportioned modernization of the US Armed Forces. This in combination with the economic crisis prevented the US to meet this goal neither qualitatively, nor quantitatively.

Bush's successor, Barrack H. Obama has recognised these failure immediately. In reaction, he has introduced his own National Security Strategy, which has reflected on the above-mentioned 
facts. Obama's National Security Strategy departs from ideas of neoconservativism. Unlike George W. Bush, President Obama believes that foundation of the US security and power does not come from abroad but it lay at home. It is an economic power of the nation. Therefore, the primary goal must be economic recovery in order to overcome the hardship of economic crisis and to boost the US economy. In his Strategy, Obama also has left the term "War on Terror", as well as the US readiness to conduct pre-emptive strikes. He has rather declared the US commitment to deal with security issues via the standards of international law and international cooperation. However, he has left the room for military action if necessary. In short, it can be said that Obama has recognised that the US dominancy cannot be backed by weapons but rather by values for which the US stands for.

The neoconservativism had not direct impact only on the US foreign policy, but also on the foreign policy of the European Union (EU) and consequently on the Slovak Republic as well. Unfortunately, it was a negative impact. While after the September 11 terrorist attacks all the EU members, as well as the countries joining the EU in 2004, unconditionally backed the US in its involvement in Afghanistan, in the period from 2003 to 2008, the situation was different. With invasion of Iraq, the EU was politically divided on countries supporting and opposing Bush's approach. This division openly supported by several US top senior officials created an environment of distrust within the EU. The EU was unofficially divided on "Old Europe" and "New Europe". While "Old Europe", represented by fully established and tenured EU members such as Germany and France, was opposing the Bush's actions in foreign policy, while the "New Europe" composed of predominantly new member states was following Bush's perception of the foreign policy unconditionally. The Slovak Republic was not exception. In 2003 the Government of the Slovak Republic unconditionally committed its Armed Forces into Iraq and Afghanistan regardless of the domestic public opinion. Moreover, it continued to maintain its military presence in Iraq despite the official reason of military intervention was proved to be a fabrication from Bush's administration. The Slovak military presence, as well as the military presence of other newly admitted EU members, in Iraq served purely for political purpose of Bush's Administration to justify this operation as an international operation. The bottom line is that Bush's foreign policy, strongly influenced by neoconservativism, undermined the US international reputation for years to come, as well as it weakened global security for a long run.

\section{References}

[1] NECAS, P., KELEMEN, M.: War on Insecurity: Calling for Effective Strategy, Kyjev, 2010, p. 14, ISBN 978-611- 01-0023-6.

[2] NECAS, P., KELEMEN, M.: War on Insecurity: Calling for Effective Strategy, Kyjev, 2010, p. 15, ISBN 978-611-01-0023-6.

[3] NECAS, P., KELEMEN, M.: War on Insecurity: Calling for Effective Strategy, Kyjev, 2010, pp. 16-17, ISBN 978-611-01-0023-6.

[4] ROBINSON, P.: Dictionary of International Security, Polity, 2008, p. 135.

[5] KRAUTHAMMER, CH.: Charlie Gibson's Gaffe. The Washington Post. Available at: http://www.washingtonpost.com/wp-dyn/ content/article/2008/09, 2002

[6] BUSH, W. G.: Bush State of the Union Address. Available at: http://archives.cnn.com/2002/ALLPOLITICS/01/29/bush.speech.txt/, 2002.

[7] BUSH,W. G.: President Bush's Speech at Westpoint. Available at: http://ics.leeds.ac.uk/papers/vp01.cfm?outfit=pmt\&folder= 339\&paper=380, 2002.

[8] BUSH, W. G.: Bush State of the Union Address. Available at: http://edition.cnn.com/2003/ALLPOLITICS/01/28/sotu.transcript/, 2003.

[9] BUSH, W. G.: Speech at the National Security University. Available at: http://www.presidentialrhetoric.com/speeches/ 03.08.05.html, 2005.

[10] BUSH, W. G.: President Bush's Address to a Joint Session of Congress. Available at: http://archives.cnn.com/2001/US/09/20/ gen.bush.transcript, 2001.

[11] MULLAH O.: Hiding in Pakistan, News, Available at: http://news.bbc.co.uk/2/hi/south_asia/6272359.stm, 2007.

[12] NECAS, P., KELEMEN, M.: War on Insecurity: Calling for Effective Strategy, Kyjev, 2010, pp. 104-107, ISBN 978-611-01-0023-6. 